\title{
THE EFFECT OF SPICE EXTRACTS ON STRAWBERRY PATHOGEN BOTRYTIS CINEREA
}

\author{
Lina ŠERNAITE், Institute of Horticulture, Lithuanian Research Centre for Agriculture and Forestry, Kauno Str. 30, LT-54333 Babtai, \\ Kaunas dist., Lithuania; 1.sernaite@1sdi.lt \\ AIma VALIUŠKAITÉ, Institute of Horticulture, Lithuanian Research Centre for Agriculture and Forestry, Kauno Str. 30, LT-54333 \\ Babtai, Kaunas dist., Lithuania; a.valiuskaite@1sdi.lt \\ Neringa RASIUKEVIČIŪTĖ, Institute of Horticulture, Lithuanian Research Centre for Agriculture and Forestry, Kauno Str. 30, LT- \\ 54333 Babtai, Kaunas dist., Lithuania; n.rasiukeviciute@1sdi.lt (corresponding author) \\ Edita DAMBRAUSKIENE், Institute of Horticulture, Lithuanian Research Centre for Agriculture and Forestry, Kauno Str. 30, LT-54333 \\ Babtai, Kaunas dist., Lithuania; e.dambrauskiene@1sdi.lt \\ Pranas VIŠKELIS, Institute of Horticulture, Lithuanian Research Centre for Agriculture and Forestry, Kauno Str. 30, LT-54333 Babtai, \\ Kaunas dist., Lithuania; biochem@1sdi.lt
}

\begin{abstract}
Botrytis cinerea, the causal agent of strawberry grey mould, has become a severe problem of horticultural farms due to its genetic variability and growing resistance to frequently used fungicides. Plant disease could induce significant losses of yields and plants thus it is necessary to discover and apply novel approaches to control strawberry pathogens. In addition, chemical plant protection products can leave undesirable residues in fruits and the environment. Plant protection should be more friendly to the environment and human than already used chemical measures. One of the alternatives could be plant-based extracts, produced from aromatic and medicinal herbs, spices, fruits. Therefore, the aim of this study was to determine the in vitro effect of cinnamon bark (Cinnamomum cassia L.) and clove bud (Syzygium aromaticum L.) extracts on B. cinerea colony growth. Experiments were carried out at LAMMC Institute of Horticulture, Lithuania. Both extracts were obtained from dried material by extraction with $\mathrm{CO}_{2}$. For in vitro assay, extracts were separately mixed with potato dextrose agar in concentrations from 200 to $1000 \mu 1 / 1$, poured into Petri dishes, then each dish was inoculated with $6 \mathrm{~mm}$ diameter $B$. cinerea disc and incubated at $22 \pm 2^{\circ} \mathrm{C}$ in the dark for 7 days. The diameter of the pathogen colony was measured 2, 4 and 7 days after inoculation. Concentrations of the extracts, which demonstrated reduced growth of the pathogen, were considered to have an antifungal effect. The results showed that extracts of cinnamon bark and clove bud had a similar antifungal effect on B. cinerea and suppressed the growth of $100 \%$ from $600 \mu \mathrm{l} / 1$ concentrations 4 days after inoculation. At $600-1000 \mu \mathrm{l} / 1$, no growth of the pathogen was detected for both extracts 7 days after inoculation. However, clove bud extract considered to be more effective, as the diameter of $B$. cinerea colonies was smaller compared to cinnamon bark extract at $200-400$ $\mu 1 / 1$ concentrations. To conclude, spice extracts of cinnamon bark and clove bud demonstrated antifungal effect on $B$. cinerea in vitro and could possibly be applied for control of strawberry grey mould.
\end{abstract}

Keywords: antifungal, Cinnamomum cassia, grey mould, Syzygium aromaticum.

\section{INTRODUCTION}

Botrytis cinerea can infect a variety of plant hosts, including strawberry, tomato, onion. Grey mould, caused by this pathogen, is responsible for high losses of plants and fruit yield (Neri et al., 2016; Rasiukeviciute et al., 2018). Commonly, grey mould is controlled by the application of fungicides (Mahdy et al., 2014; Rasiukeviciute et al., 2019). However, due to the spread of the pathogens from different geographical areas and growing resistance, it is becoming harder to avoid plant disease (Nazir et al., 2018). B. cinerea has high genetic variability, and the use of chemical pesticides leads to the development of new strains of this fungus (Fernandez et al., 2014). Additionally, chemical plant protection products can leave undesirable residues in fruits and environment, and adverse effect leads to the trend of applying eco-friendly measures for control of pre- and postharvest diseases (Antunes, Cavaco, 2010). New ways of biocontrol, such as disease forecasting, application of antagonistic microorganisms, essential oils and extracts are investigated (Mahdy et al., 2014; Mirmajlessi et al., 2016; Valiuskaite et al., 2017; Zatla et al., 2017; Pretscher et al., 2018; Rasiukeviciute et al., 2019). Plants are a comprehensive source of natural compounds for the discovery of botanical products for biocontrol (Szekacs, Komives, 2017). Secondary metabolites of plants provide extracts and

Copyright () 2019 The Authors. Published by Vytautas Magnus University. This is an open-access article distributed under the terms of the Creative Commons Attribution License (CC BY 4.0), which permits unrestricted use, distribution, and reproduction in any medium, provided the original author and source are credited. 
essential oils with antifungal, antiviral, antibacterial and various other properties. Therefore, they may become active substances for alternative plant disease management (Yami, Shukla, 2016).

Cinnamon and clove are spices used for food, aromatherapy, and medicine. Overall, spices might have antiinflammatory properties (Mueller et al., 2010). In the literature, research on various effects of spices could be found. Clove extract, obtained by hydrodistillation and extraction with dichloromethane, showed antimicrobial activity against some foodborne bacteria strains (Das et al., 2018). Other authors determined the insecticidal properties of clove essential oil and its derivative (Cansian et al., 2017). Research on spices extracts against plant pathogens could be found. Cinnamon and clove essential oils together with other oils were tested against bacterial postharvest pathogens, and results showed that cinnamon oil was found to be one of the most effective (Bozik et al., 2017). The essential oil of clove inhibited the growth of Phytophthora infestans (Mazakova et al., 2018) and emulsion and nanoemulsion of cinnamon (Cinnamomum zeylanicum L.) essential oil demonstrated antifungal effect against B. cinerea and Rhizopus stolonifera (Naserzadeh et al., 2019). Regarding all mentioned properties, extracts of cinnamon and clove potentially have active substances against plant pathogens.

Extraction with carbon dioxide $\left(\mathrm{CO}_{2}\right)$ is an advanced method for obtaining oil from plants (Haddi et al., 2017). $\mathrm{CO}_{2}$ as a solvent is environment-friendly, non-toxic. The method itself allows to obtain a product without solvent residue and to keep compounds, sensitive to high temperature (Sernaite et al., 2019). $\mathrm{CO}_{2}$ extraction is suitable to be applied in the investigation of alternatives to chemical fungicides, for obtaining active substances. Therefore, the aim of this study was to determine the in vitro effect of cinnamon bark (Cinnamomum cassia L.) and clove bud (Syzygium aromaticum L.) extracts on B. cinerea colony growth.

\section{RESEARCH METHODS}

Experiments were carried out at the LAMMC Institute of Horticulture, Lithuania. For this study cinnamon (Cinnamomum cassia L.) and clove (Syzygium aromaticum L.), extracts were used. Dried cinnamon bark and clove bud were obtained (Saldva, Lithuania). The extraction of both materials was done with liquid $\mathrm{CO}_{2}$ at the following parameters: pressure 40 bar, temperature $10^{\circ} \mathrm{C}$, and time 6 hours. The $\mathrm{CO}_{2}$ gas for the food industry ("Gaschema", Lithuania) was used. The antifungal effect was investigated by mixing extracts separately with potato dextrose agar (PDA) in concentrations 0 (control), 200, 400, 600, 800 and $1000 \mu 1 / 1$. The different concentrations of both extracts were homogenized with the PDA medium. The $6 \mathrm{~mm}$ diameter single spore isolate of $B$. cinerea (strawberry) disc was inoculated in the centre of the Petri dish. Petri dishes were incubated at $22 \pm 2^{\circ} \mathrm{C}$ in the dark for 7 days. Mycelial growth of the pathogen colony was measured 2, 4 and 7 days after inoculation (DAI) in centimetres (pathogen disc excluded). Concentrations of the extracts, which demonstrated reduced growth of the pathogen, were considered to have antifungal effects. Experimental data analysed by a one-way ANOVA with the SAS Enterprise Guide 7.1 program (SAS Inc., USA). Duncan's multiple range test $(P<0.05)$ was used for comparison of obtained means of four replicates. Results in the figures are presented as means.

\section{RESEARCH RESULTS}

The antifungal effect of cinnamon and clove extract on $B$. cinerea growth was investigated on PDA by the absence or the presence of mycelium growth. Results at 4 DAI are presented in Figure 1. The growth of the pathogen was reducing respectively, with increasing concentration of investigated extract. Both extracts had a strong antifungal effect from 600 $\mu \mathrm{l} / \mathrm{l}$ concentration, as no pathogen colony growth was observed at 600-1000 $\mu \mathrm{l} / 1$. However, the cinnamon extract did not manage to reduce any growth of $B$. cinerea at $200 \mu \mathrm{l} / 1$ and had low inhibition at $400 \mu \mathrm{l} / 1$ compared to control $(0 \mu \mathrm{l} / 1)$. The diameter of the pathogen colony at $200 \mu \mathrm{l} / 1$ was $7.9 \mathrm{~cm}$, which is equal to the diameter of the control plate, and diameter at $400 \mu \mathrm{l} / 1$ was $6.44 \mathrm{~cm}$ (Figure 2). In contrast to cinnamon extract, clove extract in present research demonstrated more than half reduced diameter of the B. cinerea colony at $200 \mu \mathrm{l} / 1$ and low pathogen growth at $400 \mu \mathrm{l} / \mathrm{l}$ compared to control. The measured diameter of the pathogen colony was $3.06 \mathrm{~cm}$ at $200 \mu \mathrm{l} / 1$ and $1.15 \mathrm{~cm}$ at $400 \mu \mathrm{l} / 1$, which is more than 50 $70 \%$ lower than in control $(7.9 \mathrm{~cm})$.

The diameter of $B$. cinerea colony growth was also observed 7 DAI to evaluate the duration of the ability to suppress pathogen under-investigated concentrations. The results are presented in Figure 3. The cinnamon extract did not maintain the reduced pathogen growth at $200 \mu \mathrm{l} / 1$ and $400 \mu \mathrm{l} / 1$. The diameter of the colonies was $7.9 \mathrm{~cm}$ in both cases and became the same as in control. Whereas, clove extract was still able to suppress the growth of $B$. cinerea at lowest investigated concentrations. The colony diameter of $5.05 \mathrm{~cm}$ was observed at $200 \mu \mathrm{l} / 1$ and $2.50 \mathrm{~cm} 400 \mu \mathrm{l}$. It was still reduced by $20-60 \%$ compared to control. 600-1000 $\mu \mathrm{l} / 1$ concentration range, which had a high antifungal activity $4 \mathrm{DAI}$, had the same effect 7 DAI. B. cinerea remained inhibited at these concentrations. 

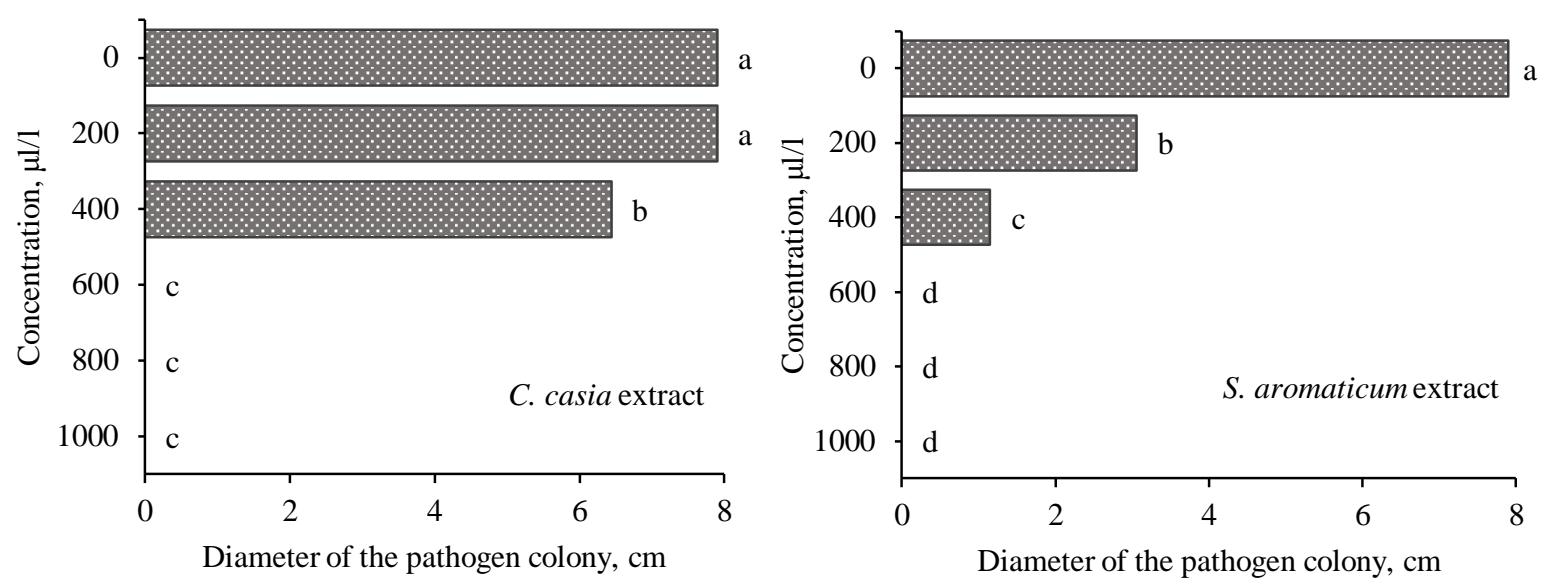

The same letter indicates no significant differences between treatments $(P<0.05)$.

Figure 1. The antifungal effect of cinnamon (C. cassia) and clove (S. aromaticum) extracts on B. cinerea colony growth at different concentrations, four days after inoculation

\section{CONCLUSIONS AND DISCUSSION}

During this study, $\mathrm{CO}_{2}$ extracts of cinnamon and clove were examined for antifungal effects against $B$. cinerea. The data presented here show that clove and cinnamon extracts have an influence on $B$. cinerea growth. The cinnamon and clove extracts completely inhibited the growth of $B$. cinerea from $600 \mu \mathrm{l} / 1$ concentration.

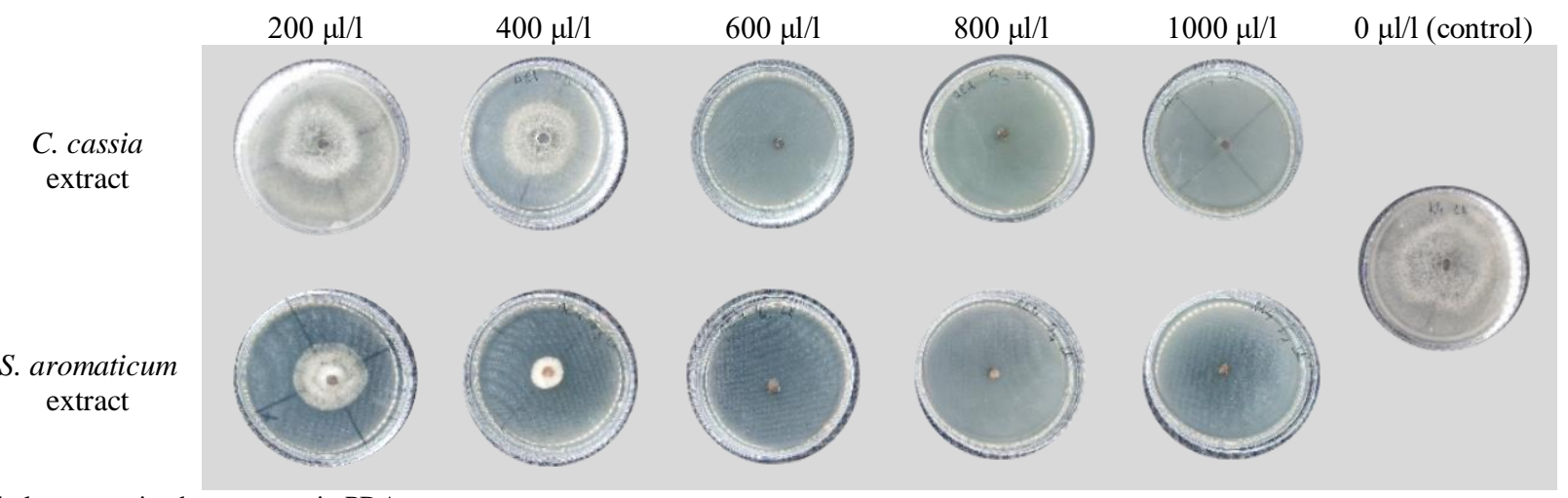

Control plates contained no extracts in PDA.

Figure 2. The diameter of B. cinerea colonies after treating with different concentrations of cinnamon (C. cassia) and clove ( $S$. aromaticum) extracts, four days after inoculation
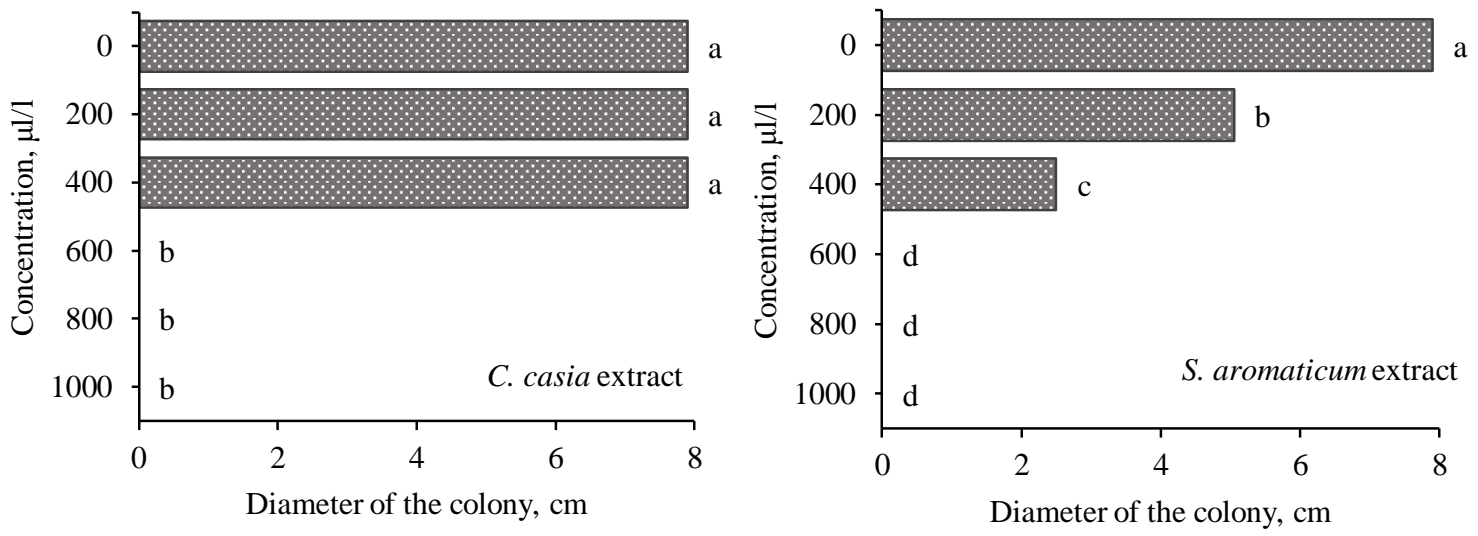

The same letter indicates no significant differences between treatments $(P<0.05)$.

Figure 3. The antifungal effect of cinnamon (C. cassia) and clove (S. aromaticum) extracts on B. cinerea colony growth at different concentrations, seven days after inoculation 
There is a lack of research on $\mathrm{CO}_{2}$ extracts of cinnamon and clove. Meanwhile, the antifungal and antibacterial properties exhibited by essential oils extracted from Cinnamomum spp. and $S$. aromaticum were reported by several researchers (Bozik et al., 2017; Mazakova et al., 2018; Naserzadeh et al., 2019).

In the Naserzadeh et al. (2019) study, cinnamon (C. zeylanicum) essential oil as emulsion and nano-emulsion form was investigated against $B$. cinerea. The results agree with our study: a complete reduction of the pathogen growth was reached from $500 \mu \mathrm{l} / \mathrm{l}$. However, emulsion and nano-emulsion of the cinnamon essential oil demonstrated more than $40 \%$ inhibition from $125 \mu \mathrm{l} / \mathrm{l}$. It could be stated that additional substances may help to make new effective forms of antifungal compounds.

Comparing the antimicrobial properties of cinnamon and clove essential oil, investigated by Bozik et al. (2017) using the microdilution method, essential oils were efficacious against three postharvest bacteria strains. Cinnamon essential oil resulted in a stronger antimicrobial effect. We gained similar efficacy of both extracts against fungal pathogen $B$. cinerea, though clove extract reduced pathogen growth at lower concentrations. In addition, clove extract maintained the reduced pathogen growth for a more extended investigated period. For such a result, clove extract is considered to have a better antifungal effect against $B$. cinerea than cinnamon extract.

Clove essential oil also showed complete inhibition of $P$. infestans mycelial growth (Mazakova et al., 2018). This effect was achieved at lower than $1000 \mu \mathrm{l} / \mathrm{l}$ concentration. Antifungal activity at similar concentrations was obtained by Hamini-Kadar et al. (2014) in the study of suppression of Fusarium spp. growth by clove essential oil. The oil completely reduced the growth of $F$. oxysporum $\mathrm{f}$. sp radicis lycopercisi and $F$. redolens at $1000 \mu \mathrm{l} / 1$ and $F$. commune at $500 \mu \mathrm{l} / 1$. Our study could agree with the concentration range of clove extract effectiveness from other studies, as complete inhibition of the pathogen growth started from $600 \mu \mathrm{l} / \mathrm{l}$.

To conclude, clove (Syzygium aromaticum L.) and cinnamon (Cinnamomum cassia L.) extracts were determined to have a high antifungal effect against $B$. cinerea (obtained from a strawberry) at 600-1000 $\mu 1 / 1$. Clove extract expressed higher inhibition at 200-400 $\mu \mathrm{l} / 1$ than cinnamon extract 4 and 7 days after inoculation. The effect of cinnamon extract had no significant difference from control at 200-400 $\mu 1 / 17$ days after inoculation. Therefore, a higher efficacy of clove extract was observed at lower concentration than cinnamon extract and the effect was longer, clove extract considered to be more effective against strawberry $B$. cinerea. The study of alternative plant protection measures is an essential strategy against occurring pesticide resistance, as well as developing environment-friendly products against plant diseases. Clove and cinnamon extracts have potential to be applied for control of strawberry grey mould.

\section{REFERENCES}

1. Antunes M. D. C., Cavaco A. M. 2010. The use of essential oils for postharvest decay control. A review. Flavour and Fragrance Journal, Vol. 25, pp. 351-366. https://doi.org/10.1002/ffj.1986

2. Bozik M., Novy P., Kloucek P. 2017. Susceptibility of postharvest pathogens to essential oils. Scientia Agriculturae Bohemica, Vol. 48, Iss. 3, pp. 103-111. https://doi.org/10.1515/sab-2017-0017

3. Cansian R. L., Vanin A. B., Orlando T., Piazza S. P., Puton S. P., Cardoso R. I., Goncalves I. L., Honai ser T. C., Paroul N., Oliveira D. 2017. Toxicity of clove essential oil and its ester eugenyl acetate against Artemia salina. Brazilian Journal of Biology, Vol. 77, Iss. 1, pp. 155-161. https://doi.org/10.1590/1519-6984.12215

4. Das A., Kannan S. K. D., Harshadka K., Raj K., Bindhu J. 2018. Molecular characterization and evaluation of antimicrobial activity of essential oils derived from Syzygium aromaticum. International Journal of Green Pharmacy, Vol. 12, Iss. 1, pp. 56-61.

5. Fernandez J. G., Fernandez-Baldo M. A. F., Sansone G., Calvente V., Benuzzi D., Salinas E., Raba J., Sanz M. I. 2014. Effect of temperature on the morphological characteristics of Botrytis cinerea and its correlated with the genetic variability. Journal of Coastal Life Medicine, Vol. 2 (7), pp. 543-548.

6. Haddi K., Faroni L. R. A., Oliveira E. E. 2017. Cinnamon oil. In: Nollet L. M. L., Rathore H. S. 2017. Green Pesticides Handbook Essential Oils for Pest Control, $1^{\text {st }}$ ed., CRC Press Taylor \& Francis Group. https://doi.org/10.1201/9781315153131-7

7. Hamini-Kadar N., Hamdane F., Boutoutaou R., Kihal M., Henni J. E. 2014. Antifungal activity of clove (Syzygium aromaticum L.) essential oil against phytopathigenic fungi of tomato (Solanum lycopersicum L.) in Algeria. Journal of Experimental Biology and Agricultural Sciences, Vol. 2 (5), pp. 447-454.

8. Mahdy A. M. M., Fawzy R. N., Hafez M. A., Ahmad T. A. L. 2014. Biological control of gray mould disease caused by Botrytis cinerea on strawberry fruits. Annals of Agricultural Sciences, Moshtohor, Vol. 52, Iss. 4, pp. 549-558.

9. Mazakova J., Zouhar M., Sedlak P., Zuskova E., Rysanek P., Hausvater E. 2018. Sensitivity to fungicides and essential oils in Czech isolates of Phytophthora infestants. Scientia Agriculturae Bohemica, Vol. 49, Iss. 2, pp. 69-77. https://doi.org/10.2478/sab-2018-0011

10. Mirmajlessi S. M., Mand M., Najdabbasi N., Larena I., Loit E. 2016. Screening of native Trichoderma harzianum isolates for their ability to control Verticillium wilt of strawberry. Zemdirbyste-Agriculture, Vol. 103, Iss. 4, pp. 397-404. https://doi.org/10.13080/za.2016.103.051

11. Mueller M., Hobiger S., Jungbauer A. 2010. Anti-inflammatory activity of extracts from fruits, herbs and spices. Food Chemistry, Vol. 122, pp. 987-996. https://doi.org/10.1016/j.foodchem.2010.03.041 
12. Naserzadeh Y., Mahmoudi N., Pakina E. 2019. Antipathogenic effects of emulsion and nanoemulsion of cinnamon essential oil against Rhizopus rot and grey mold on strawberry fruits. Foods and Raw Materials, Vol. 7, Iss. 1, pp. 210-216. https://doi.org/10.21603/2308$\underline{4057-2019-1-210-216}$

13. Nazir N., Bilal S., Bhat K. A., Shah T. A., Badri Z. A., Bhat F. A., Wani T. A., Mugal M. N., Parveen S., Dorjey S. 2018. Effect of climate change on plant diseases. International Journal of Current Microbiology and Applied Sciences, Vol. 7(6), pp. $250-256$. https://doi.org/10.20546/ijcmas.2018.706.030

14. Neri F., Cappellin L., Spadoni A., Cameldi I., Algarra Alarcon A. A., Gasperi F., Biasoli F., Mari M. 2016. Can strawberry volatile emissions influence Botrytis cinerea growth? Acta Horticulturae, Vol. 1144, pp. 37-42. https://doi.org/10.17660/ActaHortic.2016.1144.5

15. Pretscher J., Fischkal T., Branscheidt S., Jager L., Kahl S., Schlander M., Thines E., Claus H. 2018. Yeasts from different habitats and their potential as biocontrol agents. Fermentation 4 (2), pp. 31. 15. Pretscher J., Fischkal T., Branscheidt S., Jager L., Kahl S., Schlander M., Thines E., Claus H. 2018. Yeasts from different habitats and their potential as biocontrol agents. Fermentation, Vol. 4, Iss. 2, pp. 2-17. https://doi.org/10.3390/fermentation4020031

16. Rasiukeviciute N., Rugienius R., Siksnianiene J. B. 2018. Genetic diversity of Botrytis cinerea from strawberry in Lithuania. Zemdirbyste-Agriculture, Vol. 105, No. 3, pp. 265-270. https://doi.org/10.13080/z-a.2018.105.034

17. Rasiukeviciute N., Uselis N., Valiuskaite A. 2019. The use of forecasting model iMETOS® for strawberry grey mould management. Zemdirbyste-Agriculture, Vol. 106, No. 2, pp. 143-150. https://doi.org/10.13080/z-a.2019.106.019

18. Sernaite L., Urbonaviciene D., Bobinas C., Viskelis P. 2019. Optimisation of supercritical carbon dioxide extraction of lipophilic extract from rosehips. FOODBALT 2019 13th Baltic Conference on Food Science and Technology "FOOD. NUTRITION. WELL-BEING.", 188-192, Latvia University of Life Sciences and Technologies Faculty of Food Technology. https://doi.org/10.22616/FoodBalt.2019.052

19. Szekacs A., Komives T. 2017. Research directions in plant protection chemistry. Ecocycles, Vol. 3(2), pp. 4-12. https://doi.org/10.19040/ecocycles.v3i2.71

20. Valiuskaite A., Uselis N., Kviklys D., Lanauskas J., Rasiukeviciute N. 2017. The effect of sustainable plant protection and apple tree management on fruit quality and yield. Zemdirbyste-Agriculture, Vol. 104, No. 4, pp. 353-358. https://doi.org/10.13080/za.2017.104.045

21. Yami H., Shukla A. K., 2016. Antifungal activity of essential oils derived from some plants against phytopathogenic fungi. Annals of Plant Sciences 5 (7), pp. 1374-1380. 21. Yami H., Shukla A. K., 2016. Antifungal activity of essential oils derived from some plants against phytopathogenic fungi. Annals of Plant Sciences, Vol. 5(7), pp. 1374-1380. https://doi.org/10.21746/aps.2016.07.002

22. Zatla A. T., Dib M. A., Djabou N., Ilias F., Costa J., Muselli A. 2017. Antifungal activities of essential oils and hydrosol extracts of Daucus carota subsp. sativus for the control of fungal pathogens, in particular gray rot of strawberry during storage. Journal of Essential Oil Research, Vol. 29 (5), pp. 391-399. https://doi.org/10.1080/10412905.2017.1322008 